\title{
A LIVING WORTH LEAVING? ECONOMIC INCENTIVES AND MIGRATION FLOWS: THE CASE OF CZECHOSLOVAK LABOUR MIGRATION
}

\author{
Wadim Strielkowski*
}

\begin{abstract}
:
Migration studies cannot explain a paradox why migrations from regions or countries with lower economic performance to regions or countries with higher economic performance remain low even though the economic incentives of emigration are high. This gives EU stakeholders solid reasons for building serious administrative barriers and introducing "transition periods" for free movement of labour from EU-8. It is generally believed that removing barriers would cause mass labour migration. However, it might be that the problem lies elsewhere and labour migration might remain low with or without barriers. This paper analyses the pattern of Czechoslovak migrations in 1993-2004. After the split-up of Czechoslovak Federation citizens of both countries could reside and work in another country without any restrictions. This was even more simplified by the common cultural background and unique language proximity. Although the Slovak Republic was generally less successful in its economic growth than the Czech Republic, the analysis of the model of Czechoslovak migrations specified in this paper does not leed to the conclusion that economic differences between the two countries influence migration between Slovakia and the Czech Republic. It might be that economic disparities might influence migration however it happens only after they reach some critical level.
\end{abstract}

Keywords: migration, labour mobility, EU enlargement, transition economies

JEL Classification: F22, J61, C200, P3

\section{Introduction}

In general, primary determinants of migration decisions are expressed through the differences in wages and other sources of income between the host and the source countries (see for example Sjaastad, 1962; Todaro, 1969; Harris and Todaro, 1970; Walsh, 1974). However, this approach would not suffice to explain one interesting implication of modern migrations: if economic disparities between countries or regions prevail, why does volume of migration remain considerably small?

As Faini et al. (1999) point out international migration is the "great absentee" in the liberalization of global goods and factor markets. Net annual emigration rates in the

* National University of Ireland, University Road, Galway, Republic of Ireland (w.strielkowski@nuigalway.ie) and Institute of Economic Studies, Faculty of Social Sciences, Charles University, Opletalova 26, CZ - 11000 Praha 1, Czech Republic

(strielkowski@centrum.cz) 
developing countries represent less than 0.1 per cent of total populations, although the GDP per capita in these countries is less than 1/10 of that in the developed world (World Bank, 2005). Even in case of poor countries and regions that are situated very close to substantially wealthier regions (and therefore the costs of emigration are very low) such as Eastern and South-Eastern Europe, Northern Africa and Central America the net annual emigration rates are about 0.15 per cent (Brücker and Schroder, 2006).

Perhaps, one possible explanation to that moderate migration flows in case of high economic incentives is that there are high legal and administrative barriers to migration (Brücker and Siliverstovs, 2004). The existence of these barriers is heavily defended by policy-makers and the populations in the migration-receiving countries. Generally, there are fears that opening the barriers to immigration will involve a massive influx of migrants. However, this was not the situation of European Union after recent enlargements. Introduction of free movement in the context of the EU southern enlargement did not increase immigration from the South, and opening the labour markets to citizens of the EU-8 new Member States (NMS) in 1/3 of the Member States of the EU and the European Economic Area (EEA) after May 2004 has resulted in a net migration of less than 0.2 per cent of the population of the NMS, despite the GDP per capita in the NMS being approximately $25 \%$ of the average of the old EU Member States (Brücker and Schroder, 2006).

This paper attempts to show that opening the borders to migration does not necessarily cause increased influx of immigrants, even if economic disparities prevail. Besides, it analyses free movement of labour within Czechoslovak customs union in 1993-2004. The results are generalized and applied to defending opening the barriers for migrations from EU NMS as well as Bulgaria and Romania that joined the EU in 2007.

\section{Methodology}

\subsection{International Migration and the Role of Economic Incentives}

It remains largely unclear why migrations happen and what causes them, if the economic incentives are not involved. With regard to this there should be recalled an on-going debate in migration literature that is trying to defend or refute linking international migration to economic factors. Here, wage differentials between the poorer country (country of emigration) and somewhat wealthier country (country of immigration), differences in GDP per capita or differences in unemployment are claimed to provide the basis for migration, or, be its decisive factors (see for example Ravenstain, 1889; Hicks, 1932; Sjaastad, 1962; Todaro, 1969; Harris and Todaro, 1970; Walsh, 1974; Geary and O'Grada, 1989). Although it seems unreasonable to underestimate the influence of those factors, however it becomes apparent that quite often economic incentives give the way to the so-called "social factors" that most of the migration literature tries to omit (see for example Granovetter, 1982; Granovetter, 1995; Bauer et al., 2002). The so-called "social factors" include influence of the family, friends, and language barrier and positive or negative externalities provided by the immigrants' networks. No doubt that international migration would have never happened without economic "pull-fac- 
tors" , however it can be assumed that there is a strong influence of these "social" or "invisible" factors that has somewhat stronger impact on inducing migration from poor regions or countries to wealthier ones.

With regard to the above, it seems interesting to test how migration flows would behave in case if almost all possible economic and administrative barriers to migration are removed and the impact of "social" or "invisible" factors is neglectable. This should involve a natural experiment: a situation when two countries with borders open for migration apply no restriction to labour and migration flows from another party. In addition, it would be covetable that both countries have a highly-developed level of language proximity and share the same cultural and historical experience.

Analysing the recent development on European continent, it becomes clear that such an experiment has already taken place - the split-up of Czechoslovakia and creation of the Czechoslovak customs union (1993-2004). While the Czech Republic was more advanced in pursuing economic reforms and proceeding with economic transformation, the Slovak Republic was less developed and more dependent on mutual trade. Many Slovaks migrated to the Czech Republic for work, although these flows, simplified by the fact that there were no restrictions and administrative barriers, were moderate and manageable.

The Slovak Republic is country with a lower incomes and higher unemployment rate than those in the Czech Republic. At the face of various economic problems it is common for many Slovaks to leave their country and reside in the Czech Republic, both temporarily and permanently in an attempt to improve their level of life. In case of these labour migration transactional costs are marginal: citizens of the Slovak Republic do not need any residence permit, nor working visas to reside and work on the territory of the Czech Republic (registration at the nearest police office is required), language and cultural barriers are irrelevant due to the common cultural background (Czechoslovak Federation) and social ties are much more stronger than with any other country. In other words, the Slovaks are not considered to be foreigners by majority of the Czech population. The case of the Slovak Republic is of special interest, as far as it is easier for the Slovak workers to move to the Czech Republic in order to improve their economic position than anywhere else in Europe. The lack of natural and physical barriers makes this observation to be a very significant one.

There is not much evidence about regional migrations in Federal Czechoslovakia prior to the Velvet Revolution of 1989. Most of the labour migrations were temporary and were not recorded. Quite often it happened that citizens of one federal state were living and working in the other state for a number of years and then were returning back. Besides, given the formal status of Czech or Slovak citizenship in the Federation and overall similarities in the Czechoslovak socialist economy, these migrations cannot be well traced. It can only be assumed that some periphery-centre migrations (from rural areas to urban centres and especially Prague) were taking place as they happen in every country.

In the beginning of 1994 there were 17,000 Slovak citizens in the Czech Republic (16\% of all foreigners residing in the country). During three years, until 1997 this

1 The notion of "push" and "pull" factors that are leading to migrations can be often found throughout migration literature. Among the most frequent push factors are for instance unbearable or threatening conditions in the home country, while pull factor cann be for instance represented by the incentives in the country of immigration (see for example Ravenstein 1876, 1885, 1889; or Dorigo, 1983). 
number increased to 52,000 Slovak citizens (Czech Statistical Office, 2007). Migration over the Czech-Slovak border became a considerable source of mitigation of the Slovak unemployment problem only after the split-up of the Federation in 1993. For instance, $2.8 \%$ of the Slovak labour force was employed in the Czech Republic in the 1996 (Tang et al., 2000).

The similarity of the whole situation to the EU 2004 enlargement and pending EU 2007 enlargement calls for analysing the story of Czech-Slovak migrations for deriving conclusions for the EU case. In spite of some methodological difference some critics will surely point out that (i.e. the fact the Czechoslovakia has divided instead of unifying as in the case of the EU, or that the language proximity is very close) the circumstances the Czech-Slovak migration is proceeding nowadays are largely similar to the situation in which all the CEE countries found themselves after the EU accession (granted freedom of movement of persons and workers in 1/3 of EU-15 states).

\subsection{The Split-up of Czechoslovakia and the Successor States: Profiles}

Czechoslovak Federation disintegrated on the $1^{\text {st }}$ of January 1993 after more than seventy years of existence. The split-up of the Federation brought about pessimistic prognoses for both successor states. In case of the Slovak Republic the threats were in weakening caused by the division of common property and bearing relatively high costs of building a new state infrastructure. In the case of the Czech Republic it was the loss of broader internal market which was suddenly substituted by the international trade between two independent states (Dedek et al., 1997).

Table 1

Development of GDP of the Czech Republic and Slovak Republic and Its Components in 1993-1994 (growth rate in \%, expressed in 1984 fixed prices)

\begin{tabular}{|l|r|r|l|r|r|}
\hline \multirow{2}{*}{\multicolumn{1}{c}{ Czech Republic }} & \multicolumn{2}{c|}{ Year } & \multicolumn{2}{c|}{ Slovak Republic } & \multicolumn{2}{c|}{ Year } \\
\cline { 2 - 6 } \cline { 5 - 7 } & $\mathbf{1 9 9 3}$ & $\mathbf{1 9 9 4}$ & & $\mathbf{1 9 9 3}$ & $\mathbf{1 9 9 4}$ \\
\hline GDP & -0.9 & 2.6 & GDP & -4.1 & 4.8 \\
\hline Private consumption & 2.9 & 5.3 & Private consumption & -0.6 & 2.5 \\
\hline Public consumption & -0.1 & -2.3 & Public consumption & -0.4 & -3.5 \\
\hline Gross fixed capital formation & -7.7 & 17.3 & Gross fixed capital formation & -3.4 & -2.1 \\
\hline Change in inventories & -2.7 & -2 & Change in inventories & -2.9 & \\
\hline Exports of goods and services & 7.5 & 0.2 & Exports of goods and services & -1.9 & 12.4 \\
\hline Imports of goods and services & 10.4 & 7.8 & Imports of goods and services & 1.6 & 7.8 \\
\hline
\end{tabular}

Source: Czech Statistical Office, Slovak Statistics and Infostat Bratislava.

The split-up of the Federation had an impact on both states, especially in its first phase. In the year that followed the split-up, both GDP of the Czech Republic and independent Slovakia decreased by 0.9 and 4.1 per cent respectively (Table 1). Although this was the most serious decline in GDP in the whole course of transformation process, the next year GDP in both countries increased substantially.

The major impact was, of course, the decline in mutual trade between both countries. The decrease of GDP in both states was mainly caused by its stagnating volume in the first year after the split-up. The exports of goods and services from the Czech Republic to the 
Slovak Republic (in fixed prices) declined by 23 per cent, while from the Slovak Republic to the Czech Republic the decline was 15 per cent (Czech Statistical Office, 1995).

While the inflation remained at the pre-division level (around 20 per cent) the main difference was the rate of unemployment. Being quite high in the Slovak Republic at the year of the split-up (10.4 per cent) it was growing in the next years by 40 per cent (Czech Statistical Office, 1996).

Table 2

The Development of Labour Productivity and Average Wage in Economy and Industry of Czech Republic and Slovak Republic in 1993-1994 (growth rates in \%)

\begin{tabular}{|l|c|c|r|r|l|c|r|r|r|}
\hline & \multicolumn{2}{|c|}{$\begin{array}{c}\text { National } \\
\text { economy }\end{array}$} & \multicolumn{2}{|c|}{ Industry } & & \multicolumn{2}{|c|}{$\begin{array}{l}\text { National } \\
\text { economy }\end{array}$} & \multicolumn{2}{|c|}{} \\
\hline \multicolumn{1}{|c|}{ Czech Republic } & $\mathbf{1 9 9 3}$ & $\mathbf{1 9 9 4}$ & $\mathbf{1 9 9 3}$ & $\mathbf{1 9 9 4}$ & \multicolumn{1}{|c|}{ Slovak Republic } & $\mathbf{1 9 9 3}$ & $\mathbf{1 9 9 4}$ & $\mathbf{1 9 9 3}$ & $\mathbf{1 9 9 4}$ \\
\hline Labour productivity & 1.2 & 2.6 & 0.0 & 5.1 & Labour productivity & -0.9 & 5.3 & -7.3 & 7.5 \\
\hline Nominal wage & 25 & 17.1 & 23.8 & 15.7 & Nominal wage & 18.5 & 17 & 21 & 17.4 \\
\hline Real wage & 3.5 & 6.1 & 2.5 & 4.8 & Real wage & -3.8 & 3.0 & -1.7 & 3.3 \\
\hline
\end{tabular}

Source: Czech Statistical Office, Slovak Statistical Office.

The split-up of Czechoslovakia caused more problems to Slovak economy in terms of labour productivity. The growth rates of both productivity of labour, nominal wage and real wage slowed down in the first year after the division to grow with a slow rate (Table 2).

Overall, it can be stated that the Slovak Republic was more affected by the split-up of the Federation. Being a less economically developed part of the Federation with the prevailing share of agriculture, it felt upon the loss of the large internal market and had to substitute many channels of intra-national trade for international ones. Economic disparities and economic problems in the Slovak Republic which were apparent especially in the first years after the disintegration of Czechoslovakia made it searching for job in the neighbouring Czech Republic to look like quite a desirable opportunity (Figure 1).

Figure 1

Structure of Slovak Citizens' Employment in the Czech Republic (1995-2004)

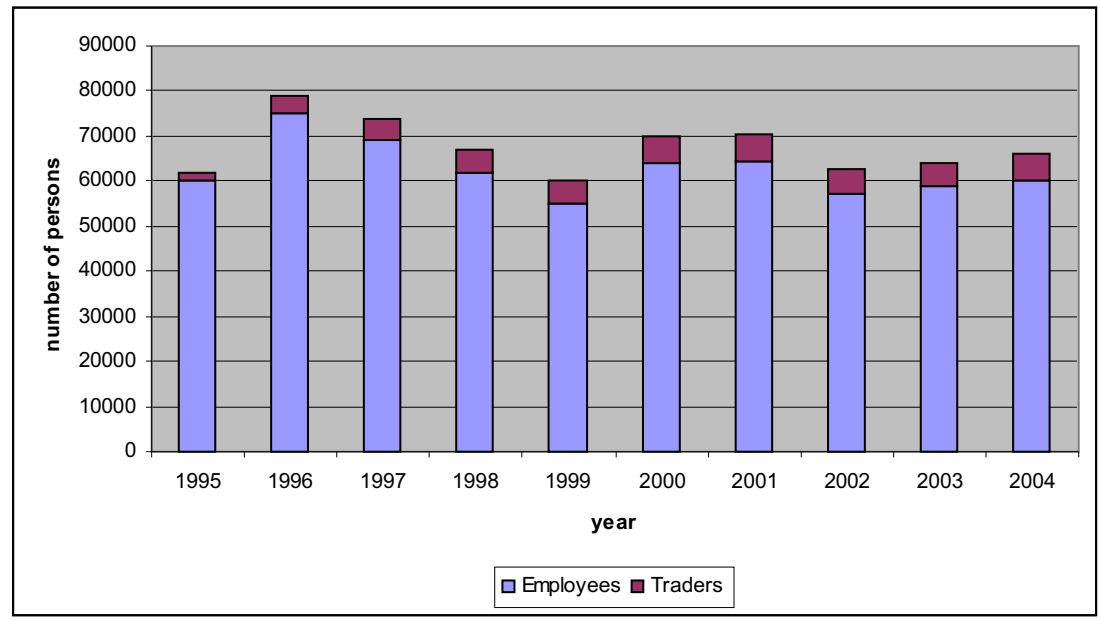

Source: RILSA (2006); Horáková (2005). 
All these, accompanied by the language proximity and the lack of administrative barriers between the Czech Republic and Slovak Republic, created an interesting natural experiment in which: (i) there existed economic incentives for migration from the country with lower economic performance (Slovak Republic) to the country with higher economic performance (Czech Republic), (ii) there were no administrative barriers to migration between the two countries in question, (iii) social factors were minimized by common cultural background of both countries (common federation for over seven decades) and language proximity of Czech and Slovak language.

The uniqueness of the Czech-Slovak migrations makes it a very interesting case that can be applied to explaining migration flows caused by economic incentives. For instance, this case shows that even in case of economic disparities and very small barriers to migration, mass influx of immigrants in the wealthier country should not necessarily be the only way the things might develop.

\section{The Data}

The data on the Slovak citizens employed in the Czech Republic include only officially registered Slovak citizens working on the territory of the Czech Republic on the legal basis in the years 1993-2004. There is no need to go beyond that data, as far as EU accession in 2004 that brought both the Czech Republic and the Slovak Republic to the European Union, has also eliminated the previous provisions and opened the door to the free movement of labour in both states (neither the Czech Republic, nor the Slovak Republic opted for the transition periods for the free movement of labour within the EU).

Thus the data comes from the reliable source and can be accepted almost without any hesitation due to several reasons: first, at the time under consideration there were no residence permits or visas for Slovak citizens in order to enter the Czech Republic; second Slovak citizens did not have to have work permit in order to start a new job in the Czech Republic; third, the registration process was simplified to minimum (informing the neighbouring police department for foreigners). All this provided a very strong incentive for the citizens of Slovak Republic living and working in the Czech Republic not to conceal their actual activities and presence in the country. Indeed, simple registration and the lack of administrative barriers made illegal unemployment useless. Slovak citizens themselves were in favour of their actual numbers in the Czech Republic being counted and registered by the organs of public administration. In addition, it is clear that those Slovaks who, in spite of all incentives, choose to be employed illegally were putting themselves to higher risk than their law-obeying countrymen. All that made the number of illegal Slovak workers irrelevant. In addition to that and due to the reasons listed above Slovak labour migration to the Czech Republic can be regarded as one of the most accurately measured and described of its kind.

The data also include: the annual difference in the GDP levels between the country of emigration and immigration calculated according to the respective exchange rates (measured by calculating the annual level of GDP in both the country of emigration and immigration in USD, then obtaining the differential of GDP levels in both countries calculated as a percentage change to the basic year of 1993); annual observations on size of economically active population (to the basic year of 1993) and measured as the people between 15 and 64 years of age (an approximation of the size of the labour market); rise 
of GDP in the Slovak Republic (to the basic year of 1993) and annual unemployment rates in both countries.

The data pool crucial for testing the impact of economic incentives on labour migration from the Slovak Republic to the Czech Republic in 1993-2004 was obtained mainly at the Czech Statistical Office and Research Institute for Labour and Social Affairs in Prague.

\section{Empirical Model}

In this section of the paper an econometric model that tries to capture the impact of economic incentives on Czech-Slovak migrations is presented. The usual form of most of the econometric models that aim to test similar causality is to relate the rate of migration to such economic factors as wages, employment and GDP per capita. For example Walsh (1974) built one of the first models of fluctuations in year-to-year migrations for Ireland. The general approach to the model adopted by Walsh in his paper and followed by others was in the following form:

$$
M_{i j t}=\alpha+\beta_{1} Y_{i t}+\beta_{2} Y_{j t}+u_{k}, k=1,2 \ldots n
$$

where $\mathrm{M}_{\mathrm{ijt}}$ is the annual rate of net migration flow from country $\mathrm{i}$ to country $\mathrm{j}$ in period $\mathrm{t}$ and $Y_{i t}$ and $Y_{j t}$ are the measures of the expected lifetime income in each country (Walsh, 1974).

Whilst most of the research literature already assumes that there is a certain impact of economic factors on migration and merely tries to test the strength of this impact, this paper examines whether and to what extent economic factors have influenced migration rate (flows of migrants expressed as net migration flows) between two countries, represented by the Czech and Slovak Republics.

Following Walsh (1974), Geary and O'Gráda (1989) and Strielkowski and O'Donoghue (2006) the model as presented in equation (1) can be extended in order to fit this empirical research and presented in a form of a multivariate statistical model in the general linear form:

$$
\log (\mathrm{M})_{i j t}=\alpha+\beta_{1} Y_{\text {diff_ijt }}+\beta_{2} D E M_{j t}+\beta_{3} Y_{j t}+\beta_{4} U_{j t}+\beta_{5} U_{i t}+u_{k}, k=1,2 \ldots n
$$

where $Y_{\text {diff } i j t}$ is the annual difference (in \%) in the GDP levels of the Czech Republic and the Slovak Republic calculated using the respective exchange rates and the year of 1993 as the baseline; $D E M_{j t}$ is the ability of the labour market in immigration country (Czech Republic) to "absorb" migration expressed as the change in the number of economically active population (to the basic year of 1993) at the age between 15 and 64 (in \%); $Y_{j t}$ is the rise of GDP (in \% to the baseline year) in emigration country (Slovak Republic) introduced in order to capture the improvement of economic conditions at home for Slovak immigrants that might become a considerable inducement for the reverse migration; $U_{j t}$ is the unemployment rate (in \%) in the country of emigration (Czech Republic); $U_{i t}$ is the unemployment rate (in \%) in the country of immigration (Slovak Republic) and $u_{k}$ represents disturbance or noise. The log-linear form of the dependent 
variable has been used due to the computational reasons, namely in order to reduce the proportions of the size of migration flows.

The hypothesis that is to be tested using the model presented in (2) can be summarized in the following way: it is likely that the inflow of labour migration can be explained by the economic differences between the two countries: one of them being the country of emigration and the other being the country of immigration. The hypothesis can be either supported or rejected on the basis of model estimation, the latter showing that the economic differences cannot influence migration of workers of any kind, at least not to the considerable level. Rejecting the hypothesis would then mean that different levels of economic development in countries that produce net outflows of labour migration and countries that are net recipients of labour migration is unlikely to be the main explanatory factor for migrations. The hypothesis which is tested on the example of the Czech-Slovak migration allows extrapolating the results on the situation in which, sooner or later, the EU will be if it decides to open its labour markets for Bulgaria, Romania and perhaps Turkey.

The results of the regression for the labour migrations of the Slovak citizens to the Czech Republic, $\log (\mathrm{M})$ are presented below (Table 3). The equation (2) has been estimated using two approaches. The first method of estimation is Ordinary Least Squares (OLS) and OLS using a stepwise regression (the threshold for entering to the model has been set at the 15 per cent significance level).

Table 3

Results for OLS and Stepwise OLS; Log of Labour Migration Log(M)

\begin{tabular}{|l|l|l|}
\hline & $\log (\mathbf{M})$ & $\log (\mathbf{M})$ \\
\hline GDP difference & $\begin{array}{l}-0.002 \\
{[0.012]}\end{array}$ & \\
\hline Economically active population in the country of immigration (Czech Republic) & $\begin{array}{l}-2.520^{*} \\
{[1.203]}\end{array}$ & $\begin{array}{l}-1.734^{* * *} \\
{[0.339]}\end{array}$ \\
\hline GDP rise in the country of emigration (Slovak Republic) & $\begin{array}{l}0.012 \\
{[0.056]}\end{array}$ & \\
\hline Constant & $\begin{array}{l}11.562^{* * *} \\
{[0.704]}\end{array}$ & $\begin{array}{l}11.605^{* * *} \\
{[0.144]}\end{array}$ \\
\hline Unemployment rate in the country of immigration (Czech Republic) & -0.096 & \\
\hline Unemployment rate in the country of emigration (Slovak Republic) & {$[0.130]$} & \\
\hline Observations & 0.054 & \\
\hline R-squared & {$[0.067]$} & 12 \\
\hline
\end{tabular}

Note: Standard errors in brackets.

${ }^{*}$ significant at $10 \%$; ${ }^{* *}$ significant at $5 \%$; ${ }^{* * *}$ significant at $1 \%$

Source: own estimations.

The coefficients of determination in both cases are very high: 0.8 and 0.72 respectively. The signs of the variables behave as expected except for the case of the variable denoting the GDP difference in both countries and the variable representing the rise of the economically active population in the country of immigration. Instead of positive signs (as expected), the estimation has yielded negative signs: this would mean that the 
higher is the difference in GDP between the country of emigration and immigration, the less would be migration flows; the second causality would mean that the larger is the labour market in the country of immigration, the less will be immigration to this country. The other variables behave as expected.

The problem is the significance of the variables: just one variable (the rise of the economically active population in the country of immigration) appears to be significant (at the 10 per cent level). In order to overcome possible problems with correlations between explanatory variables, a stepwise regression has been used to estimate (2). Again, similarly to the previous case, just one variable (the rise of the economically active population in the country of immigration) has been left in the results of the estimation. The variable is negative again and it is also significant at the 1 per cent level.

It has to be recognized that the main problem with the model specified in (2) is the fact that it uses six parameters but has only 12 observations. This considerably reduces the degrees of freedom and thus the predictive power of the model. This is due entirely to the nature of the data: Czechoslovakia ceased to exist in 1993, so today there is data available for just 14 years (and in this paper migration flows until 2004 are considered). The small data pool might have no use in the regression because the number of observations is too low for the interpretation of the regression results. Due to this problem it might be more precise to try using alternative measures of the relationships between the dependent and the independent variables in turns, taking the independent variables one by one and analysing single cases (in fact, analysing simple regression models with one dependent and one independent variable).

In order to do so, equation (2) has been modified in order to yield the following 5 equations:

$$
\begin{aligned}
& \log (M)_{i j t}=\alpha+\beta_{1} Y_{\text {diff_ijt }}+u_{k}, \quad k=1,2 \ldots n \\
& \log (M)_{i j t}=\alpha+\beta_{1} D E M_{j t}+u_{k}, \quad k=1,2 \ldots n \\
& \log (M)_{i j t}=\alpha+\beta_{1} Y_{j t}+u_{k}, \quad k=1,2 \ldots n \\
& \log (M)_{i j t}=\alpha+\beta_{1} U_{j t}+u_{k}, \quad k=1,2 \ldots n \\
& \log (M)_{i j t}=\alpha+\beta_{1} U_{i t}+u_{k}, \quad k=1,2 \ldots n
\end{aligned}
$$

Thence, it seems reasonable to proceed in this manner, computing the regressions with the help of the ordinary least squares method using one dependent (logarithm of labour migration flows from the Slovak Republic to the Czech Republic) and one independent variable.

The results of estimations of equations (3)-(7) are presented in the Table 4. The separate impact of each independent variable on the labour migration flows is shown using the sign and the value of the coefficient, the significance levels (if applicable, i.e. in case of significant variables) and the standard errors.

Although the coefficients of determination vary considerably from case to case (from 0.04 being the lowest to 0.72 being the highest) three variables have appeared to have impact on the flow of labour migrations: GDP difference, size of the labour market in the Czech Republic (economically active population) and GDP rise in Slovak Repub- 
lic (incentive to stay at home). Unemployment rates in both the Slovak Republic (country of emigration) and the Czech Republic (country of immigration) seem to have no significant impact on determining the flows of labour migration of Slovak citizens.

Table 4

Results per Individual Equations; Log of Labour Migration Log(M)

\begin{tabular}{|c|c|c|c|c|c|}
\hline & $\log (\mathrm{M})$ & $\log (\mathrm{M})$ & $\log (\mathrm{M})$ & $\log (\mathrm{M})$ & $\log (\mathrm{M})$ \\
\hline GDP difference & $\begin{array}{l}-0.013 * * \\
{[0.005]}\end{array}$ & & & & \\
\hline $\begin{array}{l}\text { Economically active population in the } \\
\text { country of immigration (Czech Republic) }\end{array}$ & & $\begin{array}{l}-1.734 * * * \\
{[0.339]}\end{array}$ & & & \\
\hline $\begin{array}{l}\text { GDP rise in the country of emigration } \\
\text { (Slovak Republic) }\end{array}$ & & & $\begin{array}{l}-0.054^{* *} \\
{[0.021]} \\
\end{array}$ & & \\
\hline Constant & $\begin{array}{l}10.955 * * * \\
{[0.077]}\end{array}$ & $\begin{array}{l}11.605 * * * \\
{[0.144]}\end{array}$ & $\begin{array}{l}11.593 * * * \\
{[0.275]}\end{array}$ & $\begin{array}{l}10.617 * * * \\
{[0.499]}\end{array}$ & $\begin{array}{l}10.605 * * * \\
{[0.309]}\end{array}$ \\
\hline $\begin{array}{l}\text { Unemployment rate in the country of } \\
\text { immigration (Czech Republic) }\end{array}$ & & & & & $\begin{array}{l}0.048 \\
{[0.045]}\end{array}$ \\
\hline $\begin{array}{l}\text { Unemployment rate in the country of } \\
\text { emigration (Slovak Republic) }\end{array}$ & & & & $\begin{array}{l}0.019 \\
{[0.032]}\end{array}$ & \\
\hline Observations & 12 & 12 & 12 & 12 & 12 \\
\hline R-squared & 0.36 & 0.72 & 0.39 & 0.04 & 0.10 \\
\hline
\end{tabular}

Note: Standard errors in brackets.

* significant at $10 \%$; ${ }^{* *}$ significant at $5 \%$; ${ }^{* * *}$ significant at $1 \%$

Source: own estimations.

The difference in GDP between the two countries has a negative impact on labour migration, the estimated coefficient is small but the variable is of the high significance (5 per cent level, R-squared is 0.36 ). This would mean that increasing or decreasing gaps in the GDP levels between the Slovak Republic and the Czech Republic does not influence the numbers of the Slovak citizens legally employed in the Czech Republic.

Contrary to the expectations summarized in Table 1 there appears to be a negative relationship between the approximate size of the labour market in the Czech Republic and the Slovak labour migration (significant at 1 per cent level, R-squared is 0.72 ). So, the larger the labour market, the less are labour migrations. This startling result might be explained by two things: (i) it might be that the size of the labour market cannot be approximated by the number of people of the working age, when it is not adjusted for the unemployment rate it might easily be that not all these people are in the job or want to take a job; (ii) it might be that the number of people of the working age in the immigration country is actually playing a reverse role - the more are the people of the working age, the higher is the competition and the harder it is for the immigrants to find a job, so many prefer to stay at home to trying their chances elsewhere. In fact, many Slovak immigrants in the Czech Republic were in low-qualified and low-paid jobs (the ones that natives rejected). It might be that due to the increase of population in the working age these jobs might be already taken. In addition to the previous, it might as well be that a large share of immigrants engages in illegal jobs that have no record in the model and therefore cannot be controlled for. The assumption concerning the negative relationship between the independent variable and the GDP rate in the country of emigration has proved to be correct (the variable is significant 
at 5 per cent level, R-squared is 0.39). This means that the rise of the GDP in the Slovak Republic (the economy will thus be better off) might make many Slovaks stay at home instead of looking for a job in the Czech Republic.

Unemployment rates in the country of immigration (the Czech Republic) and the country of emigration (the Slovak Republic) have proved to be insignificant in their relation to pre-determining the flow of labour migration and both have positive signs. This would lead to the implication that the higher is the unemployment in the Slovak Republic, the higher is the outbound labour migration, but higher unemployment rate in the Czech Republic would still mean high migration. The explanation to that might be that Slovak migrants are highly sensitive to worsening economic conditions at home, while they are indifferent to worsening of the economic situation in the target country (e.g. the labour market is so large that they expect to find employment anyway. However, very low R-squared (0.04 and 0.1 respectively) and no significance in the predictive power of the variables makes these speculations irrelevant. As far as the case of Czech-Slovak migrations is considered unemployment simply cannot be regarded as the relevant determinant of labour migrations.

Overall, it seems that in the model specified above and using the data outlined in section 3 most of the variables have no or limited impact on the rate of labour migration flows of Slovak citizens to the Czech Republic. Just one variable (rise of GDP growth rate in Slovak Republic) behaved as expected according to economic rationale, while the other four appeared to have different signs (GDP difference between two countries, approximation of the labour market size in the Czech Republic expressed as the number of people of the working age) or to have no significance at all (unemployment rates in the Czech Republic and the Slovak Republic).

To sum it up, for the model specified above migration flows are not sensitive to economic differences between the countries, even in case of extremely favourable conditions for migration prevail (absence of language barriers, social and economic similarities of the countries, cultural proximity, etc.) as it is in the case of Czech Republic and Slovakia. There is an implication that stems from that conclusion: there might be a possibility that economic differences within some magnitude have no impact on migration between two countries - a country with a lower economic performance and a country with higher economic performance. However, these economic differences might start to influence migration after they exceed some critical level. There is a legitimate hypothesis that this "critical level" can be different for different countries (as far as different countries tend to have a varying country-specific propensity to migration).

\section{Conclusions}

It becomes very clear that in a quite number of cases migration flows are not sensitive to economic differences between countries even if extremely favourable conditions for migration prevail. An example of labour migrations of Slovak citizens to the Czech Republic in 1993-2004 was used to testify this case. The results of particular model and data set used in the paper does not lead to conclusion that migrations from the Slovak Republic (a country with lower economic performance) migrations to the Czech Republic (a country with higher economic performance) under very favourable administrative conditions for migration (no visas, working permits or other administrational obstacles) 
as well as language and cultural proximity between the two countries was affected by the economic incentives and economic differences. Truly, economic differences might start effecting migration after they reach some critical level (which has not been reached in the case of Czechoslovak migrations).

The analysis of Czech-Slovak labour migrations calls for several important implications. For instance, knowing that economic differences in the Czech Republic and the Slovak Republic would be creating incentives for workers from the Slovak Republic to emigrate to the Czech Republic in a search of better jobs and knowing that barriers to this migration almost do not exist, it would be logical to assume high rate of migrations. However, knowing that under the conditions described above there were no massive labour migrations from the Slovak Republic to the Czech Republic, it seems puzzling why migration expectations from EU-8 and EU-2 (Bulgaria and Romania) are so widely discussed by the general public and justified in television and press. Instead, another postulate seems to be true: the labour market in the conditions of the European Union is sticky and expectations of inflow of labour from poorer Member States to richer Member States are not sufficiently justified.

The case of the Czech-Slovak labour migration was just an illustration of what the trends might be like after the EU accession; this specific case clearly shows that the situation does not incline to massive migration moves of workers. The thing is that even in the case of the Czech-Slovak migration the large gaps in income and problems with demography have not brought more than $2 \%$ of the emigrant-country workforce on the move. When the case of labour migration most similar to the situation in the enlarged EU provides such small impact of economic difference on the labour migration, why would it be different after the EU eastern enlargement?

It should not be forgotten that apart from the economic factors there are other factors, such as cultural, linguistic and social ties which prevent massive flows of workers from rising. It has to be remembered that these factors are often of more sense and should be taken into consideration first when talking about the labour movements. These factors and the proximity to migration as such can differ in various EU Member States.

It is more than likely that the fears of massive labour migration to the EU-25 from the new accession states will not come true as they did not come true in the case of the EU eastern enlargement and the transitional periods, which are likely to be implemented, will be merely caused by the political tensions and demands, not any considerable economic and demographic grounds.

\section{References}

Bauer, T., Epstein, G. S., Gang, I. (2002), "Herd Effects or Migration Networks? The Location Choice of Mexican Immigrants in the US," CEPR Discussion Paper Series, No. 3505.

Bauer, T., Zimmermann, K. F. (1999), "Assessment of Possible Migration Pressure and Its Labor Market Impact Following EU Enlargement to Central and Eastern Europe." Bonn : IZA, Research Report No. 3.

Brücker, H., Boeri, T. (2000), "The Impact of Eastern Enlargement on Employment and the Labor Markets in the EU Member States." Commissioned by the Employment and Social Affairs DG of the European Commission, European Integration Consortium, Berlin and Milan.

Brücker, H., Shroder, P. (2006), "International Migration with Heterogeneous Agents: Theory and Evidence." Paper presented on the Annual Labor Economics Association Conference in Prague, September 2006. 
Brücker, H., Siliverstovs, B. (2004), "The Macro-Determinants of International Migration in Europe: Evidence from Germany." Paper presented at the conference Immigration Issues in EU-Turkish Relations, Bogazici University, October 8-9, 2004.

Czech Statistical Office (2007), "Život cizinců v ČR: souborné informace." Praha : Čsú.

Dědek, O. et al. (1997), Ekonomické aspekty zániku Československa. Praha : Fortuna.

Delegation of the European Commission to Japan (2006), "European Union Enlargement: the implications for Japan." http://jpn.cec.eu.int/data/current/IMPLICATIONS_0608.pdf.

Dorigo, T. (1983), "Push-Pull Migration Laws." Annals Assn. Am. Geographērs, 73 (1), pp. 1-17.

European Commission (1999), "Towards a Europe for All Ages," Communication from the Commission to the Council [COM(1999)221 final], Brussels, May 21, 1999.

Faini, R. et al. (1999), Migration. The Controversies and the Evidence. Cambridge : Cambridge University Press.

Faini, R., Venturini, A. (1994), "Migration and Growth: The Experience of Southern Europe," London : CEPR Discussion Paper No. 964. www.cepr.org/pubs/dps/DP964.asp.

Fields, G. S. (1979), "Place-To-Place Migration: Some New Evidence." The Review of Economics and Statistics, (61) 1, pp. 21-32.

Geary, P., O'Grada, C. (1989), "Postwar Migration between Ireland and the UK," in Gordon, I. R., Thirwall, A. P., eds., European Factor Mobility: Trends and Consequences. Basingstoke : Macmillan.

Goss, E. P., Schoening, N. C. (1984), "Search Time, Unemployment, and the Migration Decision." The Journal of Human Resources, (19) 4, pp. 570-579.

Granovetter, M. S. (1982), "The Strength of Weak Ties: A Network Theory Revisited," in Marsden, P. V., Lin, N., eds., Social Structure and Network Analysis. Beverly Hills, CA : Sage Publications, pp. 105-30.

Granovetter, M. S. (1995), "Afterword 1994: Reconsiderations and a New Agenda," in Getting a Job, 2nd Ed. Chicago, IL : University of Chicago Press, pp. 139-82.

Harris, J., Todaro, M. (1970), "Migration, Unemployment and Development: A Two-Sector Analysis." The American Economic Review, (60) 1, pp. 126-142.

Horáková, M. (2005), "Labor Migration trends in the Czech Republic during the Last Decade." Praha : RILSA [VÚPSV - in Czech]. www.vupsv.cz/Horakova-TREND.pdf.

O’Grada, C. (1986), "Determinants of Irish Emigration: A Note." International Migration Review, (20), pp. 650-656.

Pissarides, Ch. A., McMaster, I. (1990), "Regional Migration, Wages, and Unemployment: Empirical Evidence and Implications for Policy." Oxford Economic Papers, (42), pp. 812-831.

Ravenstein, E. G. (1889), "The Laws of Migration." Journal of the Royal Statistical Society, (52) 2, pp. 241-305.

RILSA - Research Institute for Labor and Social Affairs [VÚPSV - in Czech] (2006), Surveys and statistical data. Praha : VÚPSV. www.vupsv.cz

Sinn, H. W. (1999), "EU Enlargement, Migration and Lessons from German Unification." Center for Economic Studies, CESifo Working Paper No. 182.

Sinn, H. W. (2000), "EU Enlargement and the Future of the Welfare State." CESifo Working Paper No. 207.

Sjaastad, L. A. (1962), "The costs and returns of Human Migration." Journal of Political Economy, 70 (5), pp. 80-93.

Tang et al. (2000), "Winners and Losers of EU Integration: Policy Issues for Central and Eastern Europe." Washington, DC : World Bank.

Todaro, M. P. (1969), "A Model of Labor Migration and Urban Unemployment in Less Developed Countries." American Economic Review, 59 (1), pp. 138-148.

Walsh, B. M. (1974), "Expectations, Information, and Human Migration: Specifying an Econometric Model of Irish Migration to Britain." Journal of Regional Science, (14), 107-120.

Walsh, B. M. (1989), "Tests for Macroeconomic Feedback from Large-scale Migration. Based on the Irish Experience: A Note." Economic and Social Review, (20), pp. 257-266

World Bank (2005), "World Development Indicators." Washington, DC : Word Bank. 